Historic, Archive Document

Do not assume content reflects current scientific knowledge, policies, or practices. 



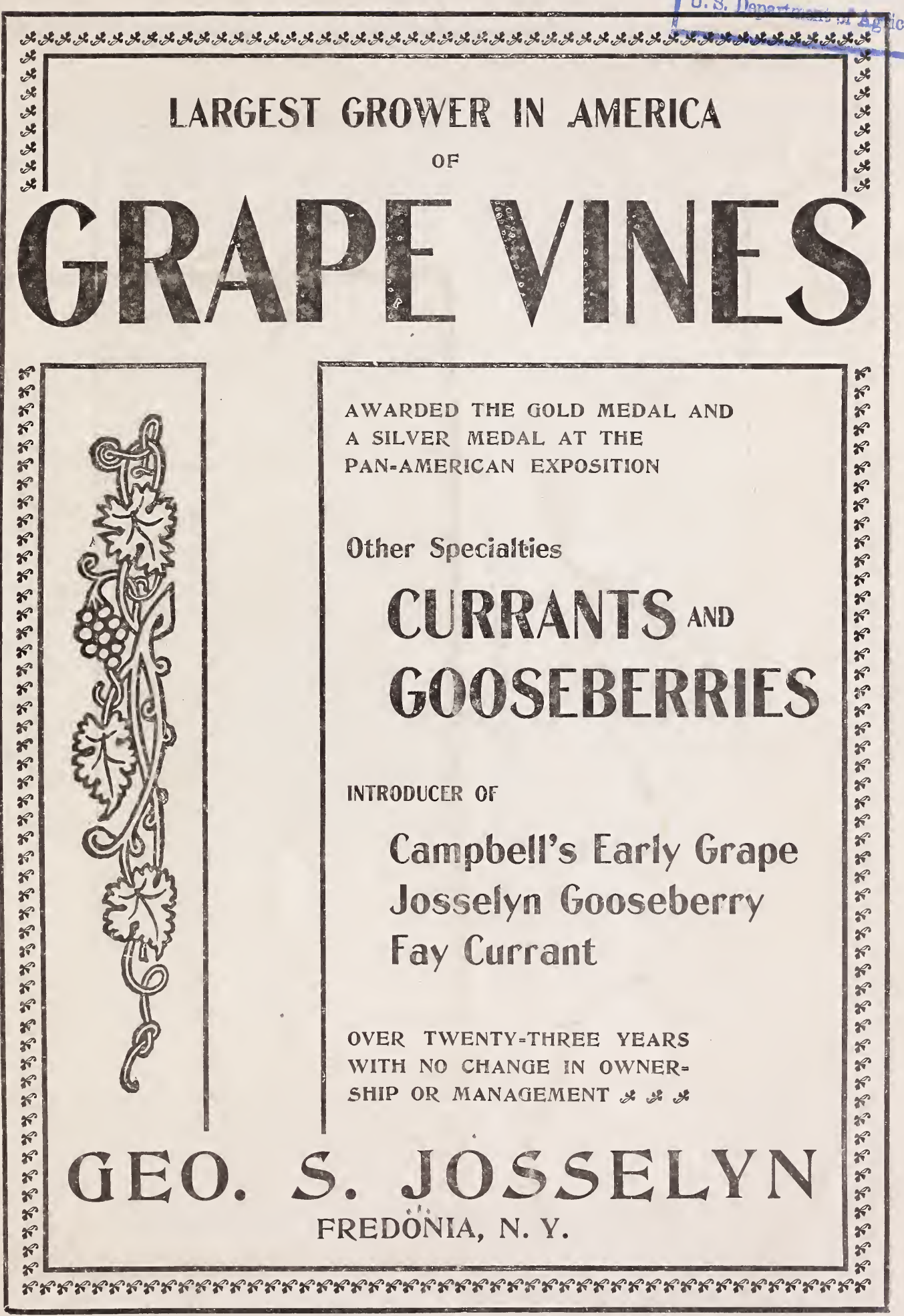




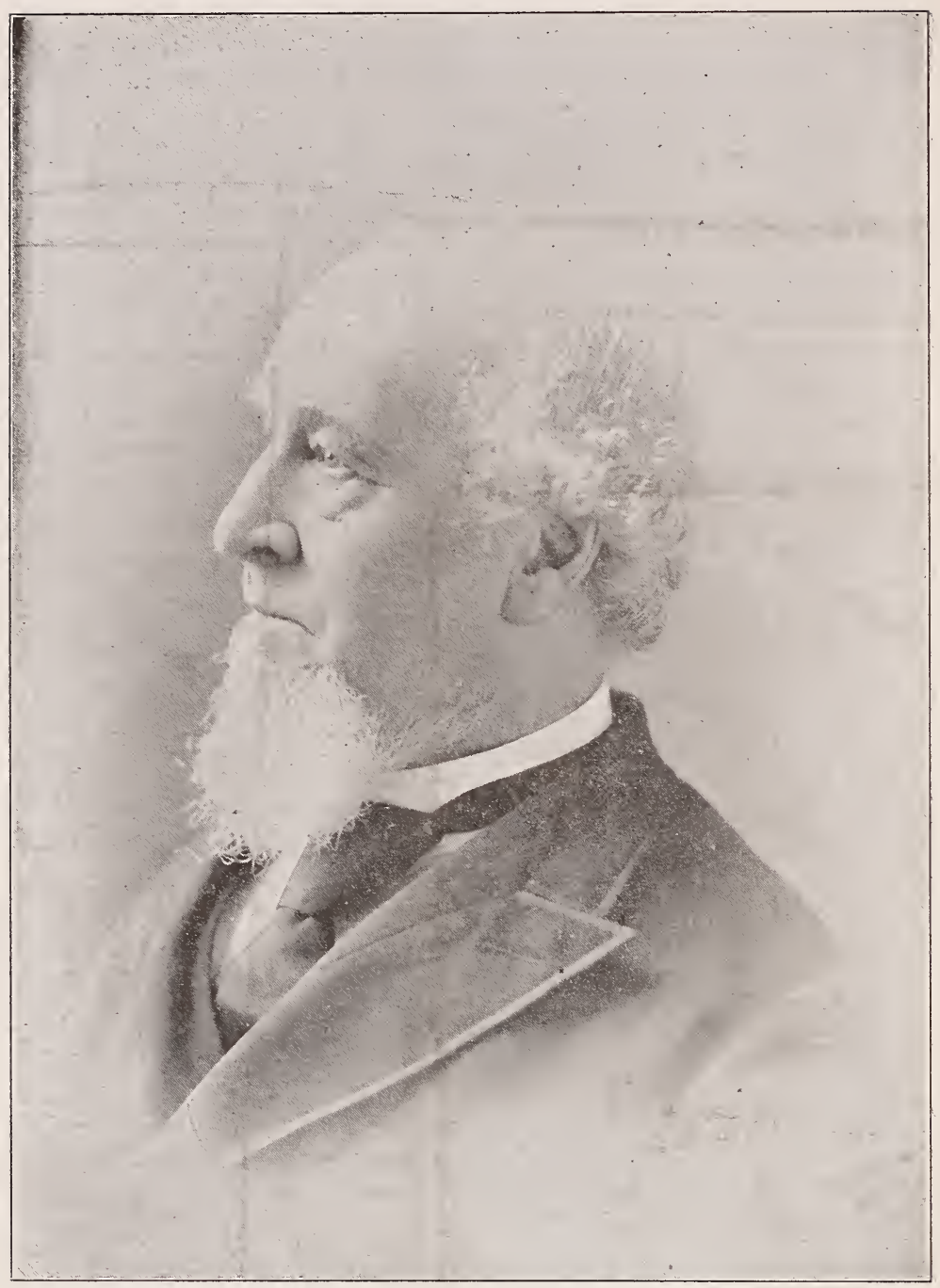

GEO. W. CAMPBELL.

DEPARTED THIS LIFE JULY 15TH, 1898. WONDERFUL AS A FROFAGATOR, ARTIST AND IN MECHANICAL SKILL, REFINED AND A TRUE GENTLEMAN IN ALL HIS SOCIAL AND EUSINESS LIFE, A DEVOTED HUSBAND AND FATHER, A STEADFAST FAITHFUL FRIEND, EELOVED BY ALL WHOKNEW HIM. TRULY ONE OF GOD'S NOBLEMEN. WE SHALL NEVER SEE HIS LIKE AGAIN.

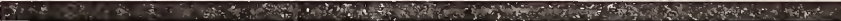




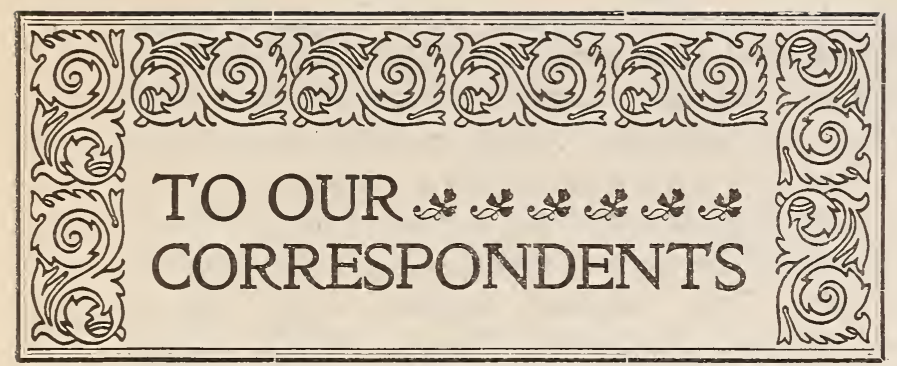

IN the year 1879 , we commenced the Nursery business in a small way, GrapeVines being our specialty. We afterwards added Small Fruits, but never found it advisable to grow other stock, because our business increased year after year, until we became the largest growers of American Grape-Vines in the World. It is nov well known that in all important occupations, specialists are most successful. An old Nursery man recently complimented me by saying, "I always read your advertisernents and circulars because there seems to be considerable individuality about them, something which cannot be copied by others." I replied that, having been in this business about a quarter of a century if 1 was not able to furnish advertisements, etc. which could not be appropriated by any Nursery concern in 'its infancy I should feel very much like either not advertising at all or quitting the ivursery business altogether.

If there is a single general Nursery, (no matter how large.) which now does a large business in growing Grape-Vines, we do not know where it is located. The trade in our specialties has for several years taxed the capacity of our entire plant to its utmost extent, and we are entirely contented with the situation, and have no desire to go into additional Nursery business. We have found that most purchasers prefer their Grape-Vines and Small Fruits direct from the grower; and we decided, some years since, to sell stock of our own growing, exclusively. The Grape-Vines, Currants, Gooseberries, Blackberries and Strawberries offered herein are warranted grown by us, and it is therefore unnecessary to say that it will be the cheapest and best way to order direct, whatever you may desire of our products.

We winter all our salable Grape-Vines, Currants, Gooseberries and Blackberries in our large, frost-proof, stone cellars, which for convenience and capacity, excel all others in our State, used for such products.

And here let us emphasize the fact, that there is se in leaving more than three buds upon a grape-vine prepared for planting. Never mind what the dealer says. If he delivers you a grape plant with a long cane, claiming that it is a "fruiting vine," and really believes that all vines should not be cut back to two or three buds at planting-time, he does not understand the business. These long-top vines are generally from localities where a good-sized grape plant cannot be grown in any reasonable time. Our two-year vines have all been transplanted, and by our method of planting and digging, we get nearly every particle of the roots. But the long-cane "fruiting vines" are left in the ground two, three, or four years; the roots run all over the neighborhood, and cannot be dug (except by hand, generally costing more than the price of the vine) without sadly mutilating the roots, leaving only aged stubs, about as destitute of fibre as a billiard ball, which the vendor offers with the offset of a long cane. According to our experience, such vines cannot be given away to any intelligent vineyardist. We fully believe that not one grape-vine in twenty which is sold to amateurs, produces a good crop of first-quality fruit, because the top is not cut back sufficiently during the first two years of its life in the garden. Many of our largest customers who buy our heaviest grades of grape- 
CAMPBELL'S EARLY-See full description, page 12.

CATAWBA-Red. Well known. Late, of best quality, but does not succeed in all localities.

CENTENNIAL - Nearly white. Bunch medium to large. Quality good. Ripens with Concord and somewhat resembles Delaware in flavor.

CHAMPION-Black. Bunch of medium size, berry large, very vigorous and productive. One of the earliest grapes, somewhat similar to Hartford; desirable on account of its early ripening. Quality poor.

CLINTON_Black. Late. Desirable for wine or preserving. Bunch and berry small; very healthy and hardy. Fruit should hang on the vine until after first frost, to be thoroughly ripe.

CONCORD-This has been for many years the grape for the million. Bunch and berries large. Black, fair quality, medium early. Vine very healthy, hardy and productive. The most extensively planted grape in America.

CONCORD CHASSELAS - Amber. Ripens with Concord, tender and melting, berries large and sound.

CONCORD MUSCAT - Greenish white. Bunch long, berries very large, tender and high flavor. Medium early.

COT'TAGE-Similar to Concord, but earlier and rather better in quality. Black, strong and vigorous.

CYNTHIANA - A Southern black wine grape, similar to Norton's. Late.

DELAWARE-Ripens before Concord. This has been considered by many, one of the best, if not the best, American grape. It does not succeed in all localities. Requires strong soil and good culture. Light red, hardy; bunches and berries of medium size.

DIANA--Red. Ripens soon after Concord. Bunches medium and compact. Good grower, with peculiar flavor, much liked by some, and disliked by others.

DRACUT AMBER-Pale red. Very early and productive. Bunch and berry large. Is quite foxy-valuable only for extreme North.
DUCHESS-Pale, greenish yellow. Tender, juicy spicy. Excellent quality and good keeper. Ripens soon after Concord.

EARLY OHIO - Black. Very early. Does not crack or shell. This grape is gaining in favor as it grows older, which is entirely appropriate as it has in times past been unreasonably abused.

EARLY VICTOR - Black. Earlier. smaller, and better flavored than Concord. Is vigorous, healthy, hardy and productive.

EATON-Large, black; ripens rather later than Concord, which it resembles in many respects; but we have seen the fruit much larger than Concord in bunch and berry.

EL DORADO-White, healthy, hardy, vigorous and productive. Ripens about with Concord, or a little before. A grape for amateurs, but does not succeed in all localities. Has imperfect blossoms.

ELVIRA-Of more value South than at the North. Pale green, late, very vigorous. and productive. Bunch and berry medium and very compact. One of the best white wine grapes at the South.

EMPIRE STATE - White, of fine quality; medium early, vigorous and hardy, and is a good keeper. Not valuable in most localities.

ESTHER-White. Ripens a few days earlier than Concord. Larger than Niagara or Pocklington. Very showy and fine quality. About the best white grape on our grounds.

ET'TA-White. Said to be an improvement on Elvira, but is larger and a little later.

EUMELAN-Black, of best quality for table or wine. Generally a poor grower; not desirable for extensive planting, but valuable for amateur culture. Early.

FRANCIS B. HAYES-Amber yellow. Pure native. Very early, hardy and pro. lific. Ripens seven to ten days before Concord.

GAERTNER (Rogers No. 14)-Red. Bunch and berry medium, early, healthy and excellent. 
GENEVA-Yellow. Not a very strong grower. Healthy and hardy. Bunch medium; berry large, fair quality, which is improved by keeping. A little earlier than Concord.

GOETHE (Rogers No. 1)-Bunch large and rather loose. Berries very large, pale red. This grape, as compared with other Rogers' Hybrids, has more individual character of its own than any other. Excellent for table or for wine. Ripens with Catawba.

GREEN MOUNTAIN (or Winchell) -White, very early. Berries drop from the stem, and it is not a good shipper. A fine grape for amateurs, however.

GREIN'S GOLDEN-Light red. Tender, juicy and sweet. Is later than Concord, and is not very desirable for table or market.

HARTFORD-Black. Bunch and berry large. Sweet. Earlier than Concord. Strong grower, healthy, hardy and very productive. Should be picked as soon as ripe, or berries will drop from the stem. Quality poor.

HERBEMIONT - A Southern wine grape. Bunches large, berries small. Excellent in the South. Black. Late at the North, and requires protection.

HERBERT (Rogers No. 44)-Black. Sweet, tender, delicious. Early and productive. One of the best $c_{f}^{f}$ the Rogers.

IONA-Red. A fine grape of excellent quality. Ripens between Concord and $\mathrm{Ca}$ tawba. Is subject to mildew in many localities, and not reliable for general vineyard culture.

ISABELLA-Black. Late. A well known old variety, vigorous and productive. Nct entirely hardy.

IVES-Black. A popular wine grafe. Strong grower, productive. Succeeds everywhere except in extreme North. Late.

JANESVILIE-Early. Vigorous, strong grower. Black. Hardy and productive. Largely planted in the North.

JEFFERSON-Red. One of the best red grapes. A good grower, hardy and productive. Ripens a little before Catawba.

JESSICA - White. One of the earliest ; fine quality Bunch and berry small.
JEWEL - Small, black, hardy and healthy. Quality good. Is earlier than Concord.

LADY - Greenish yellow, very early. Bunch and berry medium large. Is healthy, hardy, productive and of good quality. One of the best early white grapes.

LADY WASHINGTON-White, vigorous and rapid grower. Bunch large to very large; flesh soft, sweet, tender and very good. Ripens soon after Concord.

LINDLEY (Rogers No.9)-Red. Everything desirable as to quality for table or wine. Is a strong grower. healthy and hardy. Should be in every garden, and is desirable for extensive planting. Early.

LUTIE - Red. Foxy, quality medium. Vigorous, productive. Ripens with Moore's Early. This grape seems to be much in favor at the South.

McPIKE-A seedling of and ripens with Worden with all the good qualities, flavor, habits and appearance of Worden.

MARTHA-White. One of the most popular of the old white grapes. Sweet, quality betier than Concord. Fair grower, healthy and hardy. Medium early.

MASSASOIT (Rogers No. 3)-Red, Bunch and berries large. Without pulp, tender, sweet. Season same as Hartford. Vigorous, healthy, hardy, productive; good quality. About the earliest of the Rogers' Hybrids.

MERRIMAC (Rogers No. 19)-Black. Bunch medium, berry very large. Medium early; quality good; vigorous and productive.

MILIS-Black, very weak grower; ripens about with Concord. Bunch and berries very large ; quality excellent.

MISSOURI RIESLING-A white wine grape; very hardy, healthy and productive Ripens about ten days after Concord.

MOORE'S DIAMOND-Color white. Bunch and berries large Healthy, strong: grower, hardy, and where known, is very popular. Quality excelient. This new grape. has evidently come to stay. Ripens witbs Delaware. 
MOORE'S EARLY-Black ard very valuable. Two to three weeks earlier than Concord. Bunch medium, berries larger than Concord. It has taken first prize at Massachusetts Horticultural Society for many years. Should be in every garden.

MOYER-Red. Resembles Delavare in appearance. Vigorous, healthy and hardy; very early. Of not very good ouality, and unproductive.

NIAGARA - White. Quality abo 1 like (and ripens soon after) Concord. Bunch and berry large; vigorous, productive, healthy and hardy.

NOAH-White. Healthy, vigorous and very productive. Highly recommended for table and wine. Late.

NORTON'S-Black. Bunch long, berry small. Ripens late. Vigorous, healthy, hardy and productive. A valuable wine grape.

ONEIDA-Red. Healthy, hardy, and of good quality. Not very valuable.

ORIENTAL - Resembles Catawba in flavor and color, but much larger in bunch and berry, and much earlier. Vigorous and hardy. Not valuable.

PERKINS-Pale red. Bunch and berries medium. Ripens between Hartford and Concord. Is vigorous, healthy, hardy and productive.

POCKIINGTON-White. Very large and showy. Vine very hardy and vigorous. Bunch and berry large. Ripens about with Concord. Quality better than Concord.

POUGHIKEEPSIE RED-Is somewhat like Delaware in color and taste, but is larger in bunch and berry. Ripens with Hartford. With us it is a poor grower.

PRENT'ISS-Yellowish green. Bunch large, berry medium to large. Tender, sweet, melting and juicy. Hardy and good keeper, but a very weak grower. Ripens with Concord.

REQUA (Rogers No. 28;-Red. Bunch large, berry medium. Tolerably vigorous, early and productive. Sweet and good.
ROCKWOOD - Black. Ripens with Moore's Early. Large size, healthy, hardy, prolific and delicious in quality.

SALENI (Fogers No. 22 or 53)-Red. Bunch and berry very large. Healthy, hardy and vigorous. Early, good keeper, best quality for table or wine.

TELEGRAPH-Black. Ripens about with Hartford. Bunch above medium, very compact and extremely attractive. Berry medium; very vigorous, healthy, hardy and productive. Quality poor.

TRIUMPH-White. Bunch and berry very large. About as late as Catawba. Ouality good. Succeeds well in the South.

ULSTER PROLIFIC - Red. Earlv of good quality and very produciive. Inclined to overbear. If so, a part of the fruit should be picked before ripening.

VERGENINES-Red. Bunch and berry large, flavor rich. Medium early, a good keeper, and a very promising grape. A little later than Concord.

VICTORIA (Miner's)-In quality one of the best. White. Good grower, hardy and prolific. Medium to large.

WILDER (Rogers No. 4) - Black. Bunch and berry large. Early, hardy, healthy and productive ; good keeper, profitable and excellent quality. Ripens about with Concord.

WOODRUFF RED-Very large and handsome. Color red. Strong grower, very healthy and hardy. If not of the best quality, we have seen the fruit eaten and pronounced delicious by several good judges. A few days lat.: than Concord.

WORDEN - Black. Bunch and berry large ; fruit better than Concord, also earlier and larger. Vine vigorous, healthy, hardy and productive. Is becoming very popular.

WYOMING RED-One of the earliest red grapes. Bunch and berry rather small. Vine healthy, hardy and mnderately vigorous. Sweet and desirable. 


\section{CONDENSED PRICE LIST.}

FOR SPRING OF 1903.

\section{GEO. S. JOSSELYN, Fredonia, N. Y.}

\section{TO OUR CUstomers :}

$7 \pi \mathrm{E}$ offer the largest stock of Grape Tines in the World, and facilities for conduct4 ing this business EQCALED BY NO OTHER FIRM. Inspection of our stock, conreniences for doing this business, etc., will be conclusice to you that what we say is true. We commence packing in the Fall about October 1st. We store our Grape-Vines in Winter, in cellars, for Winter shil ment by mail or express, or by freight after March 1st. No orders for less than $\$ 5.00$ sent C. O. D. WE Do xоT scBstitete. We guarantee safe arrival in good condition, of rines and plants by mail.

Some nurserymen send small vines by mail and admit it. Many others mail small rines and don't admit it. The rines me send by mail are of our largest and rery best, strictly first class in every respect. For those who mail small stock which is well known to the trade as "MIAILING SIZE" about any small order would be profitable because the plants cost little and the postage on such plants is a small amount. We kindly remind our patrons that it does not pay us to sell our first class stock at prices herein in orders amounting to less than $\$ 1.00$. For all orders which amount to less than $\$ 1.00$ ten cents in addition to price of order must be sent.

Terms, cAst with order, by New York draft or post-office order, or express order on Fredonia, X. X., which is also a foreign Money Order P. O. Registered letters at our risk. Please do not fail to plainly give name, Post Office, County, State, and when ordering, give shipping directions if you wish goods sentby special route. We will accept postage stamps, 1 and 2 cent, to the amount of $\$ 5.00$; other denominations to amount of $\$ 1.00$.

Please note that there is no charge for BoxING or PACKING anything on this list.

Each variety is carefully labeled, and packing done in the best manner.

Purchasers wishing plants sent C. O. D. will please enclose one-quarter the amount of bill with order. Those sending individual checks, will please enclose 25 cents extra for exchange, for amounts less than $\$ 25.00$.

Should any stock not prore true to name, we will either refund the purchase money for same, or replace with stock true to name free; and while we are exercising great care to prevent mixtures, the abore is to be a condition on which all stock is delirered and we are not to be held liable for damages in addition to abore amount.

We reserve the right, unless otherwise directed, to fill orders for one-rear stock with two-years stock of same size. Also orders for two-rears stock, with one-year stock of size ordered.

Stock not priced in this list we cannot furnish.

If you wish a large quantity of stock and will send us a list, stating kinds, quantities, age and grade required, we will send you special prices.

We hare nerer had this pest on our grounds or premises. We beliere the best way to manage this scale is to KEEP IT OUT and have used strenuous methods to accomplish this. We hare observed that one easy way to acquire this scale is to exchange stock with "Tom, Dick and Harry" from anywhere and everywhere. Tle haven't made an exchange deal for stock in more than fifteen rears and don't propose to begin. 


\section{No. 10. Certificate of Inspection of Nursery Stock.}

This is to certify that the stock in the nursery of Geo. S. Josselyn of Fredonia, County of Chautauqua, State of New York, was duly examined in compliance with the provisions of Chapter 519 of the Laws of 1902 , and it was found to be apparently free in all respects from any contagious or infectious disease or diseases, or the San Jose scale or other dangerously injurious insect pest or pests.

This Certificate expires June 30, 1903.

Dated Aug. 28th, 1902, Albany, N. Y.

C. A. Wieting, Com. of Agriculture.

\section{GRAPE-VINES.}

IVE PREPAT MAIL OR EXPRESS CHARGES AT SINGLE OR TEN RATES.

Six or more at ten rates. Will furnish 50 or more at 100 rates.

IVE DO NOT PAY EXPRESS OR FREIGHT CHARGES AT 100 RATES

One-year No. 2 vines, 70 per cent. of the price of one-year No. 1. Two-years No. 11/2 vines, half way between prices of two-years No.1 and one-year No.1. Three-Tears No.1 (including CAMPBELL'S EARLY) one-half additional to the price of two-years.

It may not be generally known to our customers that there is not, never was and probably never will be any uniform standard for grading grape vines. So there is as much difference in size of No. 1 vines as there is in the men who sell them.

\begin{tabular}{|c|c|c|c|c|c|c|}
\hline \multirow{4}{*}{ DESCRIPTION. } & \multicolumn{6}{|c|}{ FIRST CLASS VINES. } \\
\hline & \multicolumn{3}{|c|}{ ONE Year No. 1.} & \multicolumn{3}{|c|}{ TWO YEARS NO. 1.} \\
\hline & \multicolumn{2}{|c|}{$\begin{array}{l}\text { By Mail } \\
\text { Postpaid. }\end{array}$} & \multirow{2}{*}{$\begin{array}{c}\text { Ex. or } \\
\text { Frt. } \\
100 \\
\end{array}$} & \multicolumn{2}{|c|}{$\begin{array}{l}\text { By Mail } \\
\text { Postpaid. }\end{array}$} & \multirow{2}{*}{$\begin{array}{c}\begin{array}{c}\text { Ex. or } \\
\text { Frt. }\end{array} \\
100\end{array}$} \\
\hline & $\mathrm{EACF}$ & 10 & & EACH & 10 & \\
\hline AGA WVAM-(Rogers 15)-Red, earl & $\$ .12$ & $\overline{\$ 1.00}$ & $\overline{\$ 5.00}$ & $\overline{\$ .14}$ & $\$ 1.20$ & $\$ 7.00$ \\
\hline 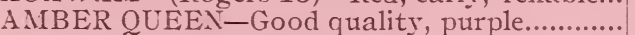 & 25 & 200 & 1500 & 30 & 250 & 2000 \\
\hline 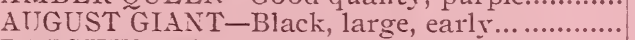 & 25 & 200 & 1500 & 30 & 250 & 2000 \\
\hline BACCHUS-Black, good.................................. & 10 & 80 & 400 & 12 & 100 & 500 \\
\hline BARRY-(Rogers 43)-Black, early, hardy..... & 14 & 120 & 700 & 16 & 140 & 900 \\
\hline BLACK DELAWWARE OR NECTAR-Black, early & 25 & 200 & 1500 & 30 & 250 & 2000 \\
\hline GHTON-Dark red, ve & 12 & 100 & 500 & 14 & 120 & 700 \\
\hline .......... & 25 & 200 & 1500 & 30 & 250 & 2000 \\
\hline CATAWBA-Red, well known, late, best quality & 12 & 100 & 500 & 14 & 120 & 700 \\
\hline CAMPBELLL'S EARLY Black, early, large, best quality & 20 & 150 & 1000 & 25 & 200 & 1500 \\
\hline CENTENNIAL-Good quality, ww & 25 & 200 & $1501)$ & 30 & 250 & 2000 \\
\hline OON-Black, v & 12 & 100 & 500 & 14 & 120 & 700 \\
\hline te, hards........ & 10 & 80 & 400 & 12 & 100 & 500 \\
\hline D-Black, & 10 & 80 & 400 & 12 & $1(10$ & 500 \\
\hline $\mathrm{GE}-\mathrm{Very}$ ea & 10 & 80 & 400 & 12 & 100 & 500 \\
\hline HIANA-Black & 14 & 120 & 700 & 16 & 140 & $9 \mathrm{CO}$ \\
\hline WARE-Red, earls, hardy, sweet. & 12 & 100 & 500 & 14 & 120 & 700 \\
\hline late good.......... & 12 & 100 & 500 & 14 & 120 & 700 \\
\hline Ay, foxy. & 10 & so & 400 & 12 & 100 & 500 \\
\hline SS-IVhit & 12 & 100 & 50 & 14 & 120 & 700 \\
\hline OHIO-Blac & 14 & 120 & 700 & 16 & 40 & 900 \\
\hline VICTOR-Very early, black. & 12 & 100 & 500 & 14 & 120 & 700 \\
\hline ather late............ & 14 & 120 & 700 & 16 & 40 & 900 \\
\hline wine grape... & 10 & 80 & 403 & 12 & 100 & 500 \\
\hline TE-II & 12 & 100 & 500 & 14 & 120 & 700 \\
\hline be & 25 & 200 & 1500 & 30 & 250 & 2000 \\
\hline $\mathrm{E}^{\prime}$ & 10 & 80 & \pm 00 & 12 & 100 & 500 \\
\hline a & 12 & 100 & 500 & 14 & 120 & 700 \\
\hline S B. HAYES-White, very & 12 & 100 & 500 & 14 & 120 & 700 \\
\hline ER (Rog. 14) ................... & 14 & 120 & 700 & 16 & 140 & 900 \\
\hline - TWhite & 25 & 200 & 1500 & 30 & 250 & 2000 \\
\hline E-(Rog. 1)-Red, 1 & 20 & 150 & 1000 & 25 & 200 & 1500 \\
\hline EN MOUNTAIN -W & 25 & 200 & 1500 & 30 & 250 & 2000 \\
\hline GR & 25 & 200 & 1500 & 30 & 250 & 2000 \\
\hline TFORD-Black, rery early........................ & 12 & 100 & 500 & 14 & 120 & 700 \\
\hline BERT-(Rog. 44) -Black, large, early,good & 14 & 120 & 700 & 16 & 140 & 900 \\
\hline A-Red, late, best quality........................... & 12 & 100 & 500 & 14 & 120 & 700 \\
\hline BELLA-Black, late................. & 12 & 100 & 500 & 14. & 120 & 700 \\
\hline -Black, late....................... & 10 & 80 & 400 & 12 & 100 & 500 \\
\hline JAN & 12 & 100 & 500 & 14 & 120 & 700 \\
\hline JEFFERSON-Red, late, valuable. & 14 & 120 & 700 & 16 & 140 & 900 \\
\hline
\end{tabular}




\section{Grape-Vines.}

\begin{tabular}{|c|c|c|c|c|c|c|}
\hline \multirow{4}{*}{ DESCRIPTION. } & \multicolumn{6}{|c|}{ FIRST CLASS VINES. } \\
\hline & \multicolumn{3}{|c|}{ One Year No. 1.} & \multicolumn{3}{|c|}{ Two Years No. 1.} \\
\hline & \multicolumn{2}{|c|}{$\begin{array}{l}\text { By Mail } \\
\text { Postpaid. }\end{array}$} & \multirow{2}{*}{$\frac{\begin{array}{c}\text { Ex. } \\
\text { or Frt. }\end{array}}{100}$} & \multicolumn{2}{|c|}{$\begin{array}{c}\text { Br Mail } \\
\text { Postpaid. }\end{array}$} & \multirow{2}{*}{$\frac{\begin{array}{c}\text { Ex. } \\
\text { or Frt. }\end{array}}{100}$} \\
\hline & EACH & 10 & & $\mathrm{EACH}$ & 10 & \\
\hline JESSICA-White, good, early & $\$ 14$ & $\$ 1.20$ & $\$ 7.00$ & $\$ 16$ & $\$ 1.40$ & $\$ 9.00$ \\
\hline JEWEL-Black, hardy, early ... & 25 & 200 & 1500 & 30 & 250 & 2000 \\
\hline LADY-White, rery early, best quality ..... & 12 & 100 & 500 & 11 & 120 & 700 \\
\hline LADY WASHINGTON-White, late, excellent.. & 25 & 200 & 1500 & 30 & 250 & 2000 \\
\hline LINDLEY - (Rogers 9) -Red, early, good ......... & 10 & 80 & 400 & 12 & 100 & 500 \\
\hline LUTIE-Red, rery early ............................. . & 12 & 100 & 500 & 14 & 120 & 700 \\
\hline MARTHA-White, early, good ....................... & 12 & 100 & 500 & 14 & 120 & 700 \\
\hline MASSASOIT-(Rogers 3)-Red, early, good & 12 & 100 & 500 & 14 & 120 & 700 \\
\hline 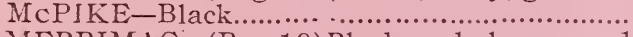 & 25 & 200 & 1500 & 30 & 250 & 2000 \\
\hline MERRIMAC-(Rog.19) Black, ea & 12 & 100 & 500 & 14 & 120 & 700 \\
\hline MISSOURI RIESLING, - White, wi1 & 10 & 80 & 4. 00 & 12 & 100 & 500 \\
\hline MONTEFIORE-Black, sweet, fine, rather late..... & 12 & 100 & 500 & $1 \pm$ & 120 & 700 \\
\hline MOORE'S DIAMOND-White, excellent, early.. & 12 & 100 & 500 & 14 & 120 & 700 \\
\hline MOORE'S EARLY-Black, very early, valuable & 12 & 100 & 500 & 14 & 120 & 700 \\
\hline 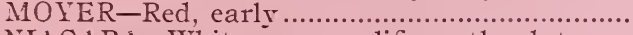 & 10 & 80 & 400 & 12 & 100 & 500 \\
\hline NIAGARA-White, very prolific, rather late... & 12 & 100 & 5̃ 00 & 14 & 120 & 700 \\
\hline H-Late, white, wine grape.................... & 10 & 80 & 400 & 12 & 100 & 500 \\
\hline NORTON'S-Black, wine grape, late........ & 14 & 120 & 100 & 16 & 140 & 900 \\
\hline PERKINS-Red, early & $1 \frac{1}{1}$ & 120 & 700 & 16 & 140 & 900 \\
\hline POCKLINGTON-Whi & 12 & 100 & 500 & 14 & 120 & 700 \\
\hline PRENTISS-White, medium early......... & 25 & 200 & 1500 & 30 & 250 & 2000 \\
\hline ROCKWOOD-Black, early, large.............. & 25 & 200 & 1500 & 30 & 250 & 2000 \\
\hline UA-(Rogers 28)-Red, early................. & 25 & 200 & 1500 & 30 & 250 & 2000 \\
\hline SALEM-Red, early, good............................. & 12 & 100 & 500 & 14 & 120 & 700 \\
\hline TELEGRAPH-Black, early, hardy, poor qual. & 12 & 100 & 500 & 14 & 120 & 700 \\
\hline ULSTER PROLIFIC-Red, very prolific............ & 12 & 100 & 500 & 14 & 120 & 700 \\
\hline VICTORIA-Miner's seedling-White, best qual & 25 & 200 & 1500 & 30 & 250 & 2000 \\
\hline VERGENNES-Red, medium early, rich............ & 12 & 100 & 500 & 14 & 120 & 700 \\
\hline WILDER-(Rogers 4)-Black, early, go sd....... & 12 & 100 & 500 & 14 & 120 & 700 \\
\hline WWOODRUFF RED-Red, good, medium early... & 14 & 120 & 700 & 16 & 140 & 900 \\
\hline WORDEN'S-Black, rery early, good................ & 10 & SO & \pm 00 & 12 & 100 & 500 \\
\hline IIYOMING RED-Red, very early, sweet......... & 12 & 100 & 500 & 14 & 120 & 700 \\
\hline
\end{tabular}

\section{SMALL FRUITS.}

Terms of shipment by Mail, Express or Freight same as Grape Vines.

GOOSEBERRIES.

\begin{tabular}{|c|c|c|c|c|c|c|}
\hline & \multicolumn{3}{|c|}{ ONE YEAR No. 1.} & \multicolumn{3}{|c|}{ Two Years No. 1.} \\
\hline & \multicolumn{2}{|c|}{$\begin{array}{c}\text { Br Mail } \\
\text { Postpaid. }\end{array}$} & \multirow{2}{*}{$\frac{\begin{array}{c}\text { Ex. } \\
\text { or Frt. }\end{array}}{100}$} & \multicolumn{2}{|c|}{$\begin{array}{r}\text { By Mail } \\
\text { Postpaid. }\end{array}$} & \multirow{2}{*}{$\frac{\begin{array}{c}\text { Ex. } \\
\text { or Frt. }\end{array}}{100}$} \\
\hline & $\mathrm{EACH}$ & 10 & & $\mathrm{EACH}$ & 10 & \\
\hline JOSSELYN,. & $\$ .20$ & $\$ 1.50$ & $\$ 7.00$ & $\$ .25$ & $\$ 2.00$ & $\$ 1000$ \\
\hline PEARL ........... & 10 & 80 & 500 & 12 & 100 & 600 \\
\hline 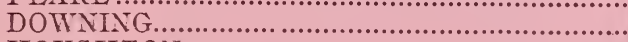 & 10 & 80 & 500 & 12 & 100 & 600 \\
\hline 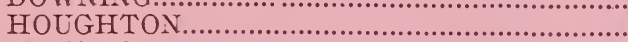 & 10 & 80 & 500 & 12 & 100 & 600 \\
\hline 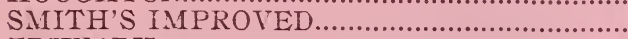 & 10 & 80 & 500 & 12 & 100 & 600 \\
\hline 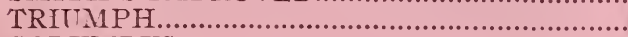 & 20 & 150 & 700 & 25 & 200 & 1000 \\
\hline COLUMBUS & 20 & 150 & 700 & 25 & 200 & 1000 \\
\hline MIOUNTAIN .................................................... & 10 & 80 & 500 & 12 & 100 & 600 \\
\hline 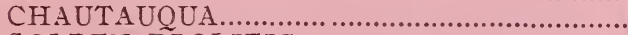 & $2 \tilde{5}$ & 200 & 1500 & 30 & 250 & 2000 \\
\hline GOLDEN PROLIFIC .............................. & 20 & 150 & $\tau 00$ & 25 & 200 & 1000 \\
\hline
\end{tabular}




\begin{tabular}{|c|c|c|c|c|c|c|}
\hline CURRANTS. & \multicolumn{2}{|c|}{$\begin{array}{l}\text { One Year, No. } \\
\text { By Mail. } \\
\text { Postpaid } \\
\text { Each Per } 10\end{array}$} & $\begin{array}{l}1 . \\
\text { Frt. } \\
\text { or Exp. } \\
\text { Per } 110\end{array}$ & \multicolumn{2}{|c|}{$\begin{array}{l}2 \text { Years; No. } \\
\text { Mail } \\
\text { Postpaid } \\
\text { Each Per } 10\end{array}$} & $\begin{array}{l}1 . \\
\text { Frt. } \\
\text { or Exp. } \\
\text { Per } 100\end{array}$ \\
\hline CHERRY.....................VERSAILLES...... &.$\$ 010$ & $\$ 080$ & $\$ 4.00$ & $\$ 012$ & $\$ 100$ & $\$ 600$ \\
\hline VICTORIA & .010 & 080 & 400 & 012 & & 600 \\
\hline WHITE GRAPE........W & 012 & 100 & 500 & 015 & 120 & 700 \\
\hline LEE'S PROLIFIC.... BLACK NAPLES.. & 010 & 080 & 4.00 & 012 & 100 & 600 \\
\hline 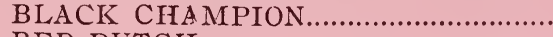 & .010 & 080 & 4. 00 & 012 & 100 & 600 \\
\hline RED DUTCH................ & 010 & 080 & 400 & 012 & 100 & 600 \\
\hline NORTH STAR............MOORE'S RUBY.. & 010 & 080 & 4. 00 & 012 & 100 & 60 \\
\hline WHITE TRANSPARENT (see note below) & 012 & 100 & 500 & 015 & 120 & 700 \\
\hline 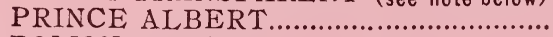 & 010 & 080 & 4. 00 & 012 & 100 & 600 \\
\hline POMONA, Red, new, ............................ & 012 & 100 & 500 & 015 & 120 & 70 \\
\hline WILDER, Red, new,....$\ldots \ldots \ldots \ldots \ldots \ldots \ldots$ & 012 & 100 & 50 & 015 & 120 & \\
\hline RED CROSS, Red, new........... & & 100 & 500 & 015 & 120 & 700 \\
\hline FAY'S PROLIFIC & 012 & 100 & 500 & 015 & 120 & 700 \\
\hline
\end{tabular}

Although it is often stated that the originators of new fruits never get much benefit from their productions, it is safe to say here, that in this respect the success of Fay's Prolific is un paralleled, as up to this date I have paid to the heirs of the originator OVER FORTY THOUSAND DOLLARS IN CASH as their share from my sales of Fay Currant plants. This is now the leading Currant, and its best recommendation is its enormous sale, constantly increasing. Ir stock of Fass is and al ways has been propagated from wood from original stock on the Fay Farm. I sell more of them than all other varieties combined, although I try to grow what I can sell of all kinds. After them than all other rarieties combined, although I try to grow what can sell of all kinds. After
growing Fays in a small way, numerous extensive fruit growers are now buying them in large lots to occupy the land formerly used for the old varieties of Currants, and evidently prefer to get the plants from the introducer, as millions of spurious Fays hare been sold.

NOTE-White Transparent Currant has taken First Prize eleren times in the past fourteen years, for best white Currant at Annual Exhibitions of Massachusetts Horticultural SocietJ.

BLACK RASPBERRIES-No.1 Plants

GREGG Each. Per 10. Per 100

SOU

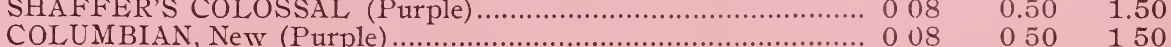

RED RASPBERRIES-No. 1 Plants.

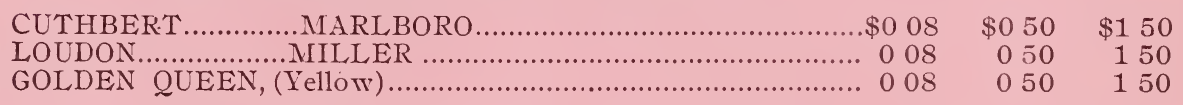

BLACKBERRIES.-NO. 1 PLANTS.

TAYLOR'S PROLIFIC.....WILSON'S EARLY .....................\$0 $10 \quad \$ 080 \quad \$ 200$

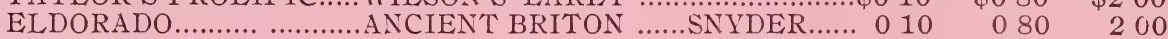

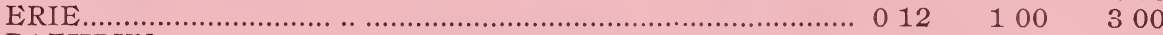

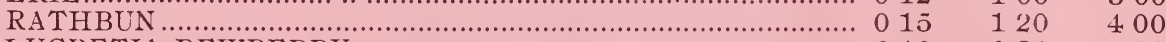

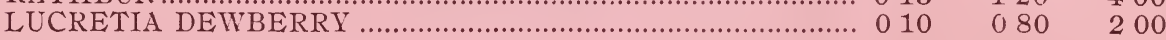

STRA WBERRIES-No. I Plants.

B 5 express or freight at 100 or 1000 rates. Fift $y$ of one kind at 100 rates. Four hundred of not more than 4 varieties at 1000 rates. These offers at 100 and 1000 rates are to go by freight or express, which charges are to be paid by the customer. If you wish Strawberries sent by mail at 100 rates, please add for postage 30 cents per 100 . We believe that a selection from our list will give complete satisfaction. Our Strawberry list does not contain as many varic ties as usual because we have discontinued growing all varieties which have proved unprofitable for fruiting with us.

All from new beds. Excellent plants in bundles of 50 with roots straight.

\begin{tabular}{|c|c|c|}
\hline & er & \\
\hline BRANDYWINE............CHAS. DOWNING........COLUMBIAN............ & $\$ 040$ & $\$ 30$ \\
\hline GREENTILLE $(P) \ldots$ & & \\
\hline IEL'S EARLY....SI & & \\
\hline IARCK $\ldots . . . \ldots \ldots \ldots . . . .$. & & \\
\hline HALL & & \\
\hline AFORD (P). & & \\
\hline
\end{tabular}

NoTE-Sample proved biggest berry and best cropper among 200 varieties fruited by Prof. Maynard at Amherst College, Mass. It has yielded at rate of 100 bushels per acre on an OLD BED. Season is late. Is pistillate, as are other varieties marked (P). 


\section{GOOSEBERRIES.}

The curse of Gooseberries is mildew. This mildew comes like a thief in the night, and after it arrives, the damage is done, and there is no use in trying to cure the plants; at least this is according to our experience. Some two or three years since, liver of sulphur was recomऊineñdeú as a preventive. We tried it faithiuliy, but it was a complete failure, and the experiment cost us more than $\$ 50.00$ There are many varieties of Gooseberries which thrive in England, etc.; but practical fruit growers have found, to their sad experience, that English Gooseberries and their seedlings are a failure in America. To avoid mildew and get a crop of Gooseberries, plant the Josselyn, which has never mildewed, to our knowledge. The market for Gooseberries seems to be never half supplied, and the demand for this fruit largely increases each year. The culture of Gooseberries should be nearly the same as for Currants. Use white hellebore, to prevent or destroy worms, same as for Currants. When planted, the tops should be cut back nearly to the crown. In our soil we can grow stronger Gooseberry roots in one year, than can be done in most localities in two years. All that has been previously herein stated concerning the value of "tops and roots" in grape-vines, is likewise applicable to Gooseberries.

CHAUTAUQUA-Supposed to be a seedling of English type. Berries large. Color yellow.

COLUMBUS - A new variety, resembling Triumph. Said to have larger fruit than Industry. Yellow.

DOWNING - Large, best quality for home use and market. Pale green in color.

GOLDEN PROLIFIC-Berries large, color yellow. Supposed to be a seedling of some English variety.

HOUGHTON'S SEEDIING-Medium size, pale red. Quite sweet and enormously productive with us.

INDUSTRY - We have never met a man yet, who has planted this Gooseberry and succeeded with it. It mildews here badly, if it does not die before the mildew arrives. We consider this Gooseberry a Eailure.

JOSSELYN-Red. The most prolific and most valuable Gooseberry in America; as large as the largest; berry smooth. Very hardy. Quality best and foliage best of any Gooseberry known. For ten years it has stood close to Triumph, Crown Bob, Whitesmith, Smith's Improved, Downing, and more than a dozen other sorts; and while these others have all mildewed in leaf and fruit, mildew has never appeared on the Josselyn.

MOUNTAIN-Red. In many particulars it resembles Houghton, but is decidedly an improvement on that variety.

PEARL-Pale green in color. We are pleased with this Gooseberry on our grounds, and although we do not consider it equal in general value to Josselyn, it has many good qualities.

SMITH'S IMIPROVED-Large. Pale yellow. Excellent quality, moderately vigorous.

TRIUMPH - Color yellow. Fruit of enormous size. Great productiveness. 


\section{CURRANTS.}

Currants should be planted in good, very fertile soil, with liberal manuring, and the tops; should be cut back nearly to the crown, allowing only three or four canes to grow the first year. Plant in rows five or six feet apart, and three feet in the row. Prune more or less every year to get rid of the old wood and keep the bushes open. Currant worms should be vigilantly looked for in Spring and Summer. These worms can be destroyed by white hellebore. one: ounce to three gallons of water, and applied with a sprinkling can. Be sure and use the remedy as soon as, or before the worms appear. In our soil we can grow stronger Currant roots in one: year than can be done in most localities in two years. All that has been previously stated concerning the value of "tops and rocts" in Grape-vines, is likewise applicable to Currants.

BLACK CHAMPION-Black. The largest of the black Currants. Is new here, but much grown and valued in England.

BLACK NAPLES-The best old, biack variety.

CHERRY-Red. The largest of all, except Fay's Prolific. Very popular in market, and brings several cents more per quart than any other old variety. Although others may say that Cherry and Versailles are one and the same, we have both varieties pure and distinct, each with its peculiar characteristics.

FAY'S PROLIFIC - This new Currant has greatly exceeded all expectations of the proprietor of this establishment, who is the introducer of Fay's Prolific, and who is often almost blamed by many in the trade who assert that we never claimed nearly enough for it. It is so good, and succeeds so well in so many localities, that not only the introducer but also the heirs of the originator, have received quite a fortune from sales of the plants. That all other varieties of red Currants have been superseded by Fay's Prolific, seems to be a fact, and the constant increase in demand for the plants is the best evidence of this. We have already paid the heirs of Lincoln Fay, the originator, over forty thousand dollars in cash as their share from our sales of Fay's Prolific, in which we have much pride. as this is about the first instance where the originator has received anything like a decent compensation from the sales of a good, new fruic. That the Fay Currant is the standard red Currant seems to be true, as we sell more of them than all other Currants combined, and from other nurserymen we hear like experience. We frequently hear of some old or new Currant destined to supersede all others, especially the Fay. We have tried to keep posted. and have carefully examined the fruit of all these so far as heard from. But, while in some: ways desirable, not one of them, on account: of size and appearance. will sell beside the: Fay, in any city or country market. The ladies have reasons of their own for selecting: and paying more per quart for the largest. most attractive and beautiful berries. We: shall welcome a better Currant than the Fay at any time, but such has not yet appeared.

In addition to pruning the old wood lib-. erally each year, about one-half of the new. wood of the Fay should be clipped off each. Autumn or Winter. Our original claim and: description was:

Color, red. As compared with the Cherry' Currant, "Fay's Prolific" is equal in size, better in flavor, much less acid, five times as prolific, and from its peculiar stem, less: expensive to pick. That spurious Fay plaris. have been sold, doubtless by the million is. not the fault of the introducer.

LEE'S PROLIFIC - Black. Prolific. One of the best.

LONDON MARKET - Red. Size. quality and time of ripening medium.

MOORE'S RUBY - Light red. Late not very acid. Fine for table or family use.

NORTH STAR-Red. A rapid grower, very hardy and excellent quality. On our grounds the size of the fruit has never been large enough to compete with Fay's, Cherry or Victoria, and we have heard like complaint from others. But in Summer of 1895 we saw at a friend's, a block of North Star, which showed bunches and berries of very" good size. Possibly our friend had more suitable soil than others for this particular variety, and we were glad to see the North Star show up so well. 
POMIONA-Red. Early. Medium size. Fine quality, rather sweet. Very popular in Indiana.

PRINCE ALBERT-Red. A bove medium in size and quality. Early in ripening.

RED CROSS - Red. Large, vigorous, sweet and fine in quality. Medium to late in ripening.

RED DUTCH-Very productive, and of good quality.

VERSAILLES-Red. Almost as large as Cherry, and very prolific.

VICTORIA - The latest red Currant, and is of good quality and prolific.
WHITE DUTCH - Medium large Sweet, fine flavor.

WHITE GRAPE-Fine quality, large and productive.

WHITE TRANSPARENT - This Currant is of French origin, obtained by us some years since from Benj. G. Smith, who has been for so many years treasurer of the American Pomological Society. We have never seen this currant mentioned in any Catalogue, but for eleven years the Massachusetts Horticultural Society has awarded Mr. Smith first prize for White Transparent as best white Currant. It has a distinct flavor, milder than White Dutch or White Grape. Larger than White Dutch, with longer bunches.

WILDER - Red. Rather large. Quality fine. Ripens in medium season.

\section{BLACKBERRIES.}

The Blackberry is naturally a stronger bush than the Raspberry, and should be planted in rows eight feet apart and three feet in the row. They should also not be pinched off, until three and one-half feet high, nor should they be so closely pruned in Spring; otherwise their culture is the same. Where land is scarce, they may be planted three by five feet apart and tied up to stakes. When Blackberries are planted, tops should be cut nearly to the crown, allowing only three or four canes to grow, the first year.

AGAWAIM - Fruit of fair size, tender, sweet to the core. For home use it has no superior. Very healthy, hardy and productive.

ANCIENT BRITONT-Pronounced by many to be the very best blackberry for fam ily use. Medium in size and sessnn.

EARLY HARVEST-Earliest; hardy, very prolific.

EIDORADO-Large, sweet, delicious. Hardy and very productive. A very promising variety.

ERIE-Large, productive, vigorous, good cuality and perfectly hardy.

KITIATINNY - Large, good; not quite hardy.

OHIVER - As large as the largest. Hardy, best quality. Sweet even before fully ripe. Very productive, strong grower. Late.

RATHBUN-Very large. Very hardy, Fruit brings higher prices than any other blackberry known. We consider this the most valuable of any blackberry.
SNYDER - Entirely hardy. Very prolific, early, sweet, and can be relied on for a crop every year.

STONE'S HARDY-One of the hardiest. Sweet and productive. Well suited to a cold climate.

TAYLOR'S PROLIFIC-Seems to be strong, and entirely hardy with us. Fruit large; very productive and of good quality.

WILSOI'S EARIY-Very large, early and good. Rather tender at the North.

WIISON, JR.-A seedling from Wilson. The original description was: "Larger, earlier and more productive than its parent." We consider it much like the Wilson.

\section{DEWBERRY.}

LUCRETIA - Large, very productive and attractive. Fine quality and flavor. Very early, and seems very hardy. 


\section{STRAWBERRIES.}

The best time to plant Strawberries is in early Spring, and on fertile, well manured land. If horses are to be used in cultivating, plant in rows three and one-half to four feet apart and one foot in the row; but for hand culture one by two feet will answer. Each bed should bear two crops. When Strawberries are planted if the ground is not wet we fill every hole full of water before the plant is inserted in the ground. If quantity of plants warrants we use a horse with barrels of water on a stone-boat. The following varieties have run out with us or have been superseded by newer and better kinds, therefore we do not offer any more Belmont, Beverly, Bidwell, Capt. Jack, Crawford, Cumberland, Ideal, Isabella, Jas. Vick, Jersey Queen, Kentucky, Manchester, Mary, May King, Miner's Prolific, Old Iron Clad, Parry, Princess, Windsor Chief and Wilson. The same Strawb erry rever fruits best two years in succession with us.

NotE.-Those marked (P) are pistillate, "have blossoms imperfect," and should have a row of some staminate variety with in fifteen feet, or they will usually produce imperfect fruit.

We have discarded all varieties which prove unprofitable for fruiting with us.

BISIMARCK - Very productive. Large. bright scarlet, firm and solid, excellent quality, no green tips; rather late

BRANDYWINE-Moderately productive of very large berries; medium to late. Should be in every garden.

BUBACH (P)-Medium to late. Berries very large, bright crimson and a fine show berry. Very productive on rather heavy land.

CHAS. DOWNING - Has doubtless held its place longer than any other old variety. A favorite for home use and market; medium in size. Dark scarlet. Season medium.

CLYDE-Early to quite late. Large to very large. Bright color. Firm, immensely productive. A wonderful strawberry.

COLUMIBIAN - Very early. Succeeds on medium light soil. Fruit somewhat like Crescent but larger. Very profitable.

CRESCENT (P) - Very early. Succeeds on light soils and will bear more neglect than any other strawberry. Has been a great favorite with fruit growers for many years.

EXCELSIOR-Extra early. One of the very best in quality and quantity of fruit. A good shipper.
GLEN IVIARY - Very vigorous, firm, enormously productive. A good family or market berry; medium early.

GREENVILIE (P) - Very productive. Quite late. Berries very large, bright crimson. A splendid market berry.

JESSIE - Large, firm. Quality good. Medium early. A great favorite in some localities.

JOHNSON'S EARLY-Very early. Is the great market berry in vicinity of New York. Never heard of its being affected with rust.

LOVET'T - Medium early. Of the old Wilson type and one of the best to take its place. Also valuable as a fertilizer of any of the imperfect flowering varieties.

MICHEL'S EARLY-Earliest and very valuable for market.

NICK OHMER - Early to very late. Berries large and beautiful. Very popular and the demand for this variety is constantly increasing.

PARKER EARLE-Late. One of the most productive. Needs rich moist land. Fruit large, good quality, dark glossy red. 
SAMPLE (P) Sample proved biggest berry and best cropper among two hundred vanieties iruited by Prof. Maynard at Amherst Agricultural College, Mass. It has yielded at the rate of one hundred bushels per acre on an OLD BED. In the year 1900 with us it not only produced the best crop and largest berries in our collection but also brought more money per quart than any other variety,

SEAFORD (P) - Season quite late. Berries big and bright. Big bearer, and of quality that will please the fastidious.
SHARPLESS-Medium late. One of the old timers which is still a favorite in many localities.

TENINESSEE-Medium to early. A fine market or family berry, thriving on quite light dry soil.

WARFIELD (P) - Very early. Succeeds most everywhere with everybody. Ships well. Great cropper and one of the best for canning or market.

WM. BELT - Medium season. Very large size. Good cropper. Brilliant glossy red. Quality good.

\section{RASPBERRIES.}

Plant Raspberries in rows six to seven feet apart, and two and one-half to three feet apapt in the row, and from two to five inches deep according to the nature of the soil. Prune canes back to one and one-half or two feet from the ground, one year after planting. When new growth gets to be about two feet high, the second season, pinch off the tip ends; and when the laterals have grown a foot long, pinch azain. This makes them stocky. In the Spring following, prune to a round-headed bush, clipping off about one-third of the wood. In this way, fine crops of large fruit may be grown, and the vigor of the bushes kept up. On sucker-sorts, leave four or five canes to the hill. All others must be hoed off, same as weeds. In small gardens the plants may be planted three by four feet apart, and the canes tied up to stakes. The canes should not be pinched until three feet high.

\section{BLACK CAPS.}

GREGG-The largest and latest of all. Very strong grower, valuable, hardy and profitable.

OHIO-Very early and productive.

PALIMER - The earliest black cap. Berries good size and showy. Canes healthy and vigorous.

SOUHEGAN-Extremely early. Said to be "Iron-clad."

TYLER-One of the earliest. Promises well. Much like Souhegan.

\section{RED RASPBERRIES.}

COLUMBIAN (New)-Purple. Very vigorous grower; canes often ten to sixteen feet in length and more than one inch in diameter. Very hardy; fruit large and delicious for table or canning. Excellent shipper.
CUTHBERT-One of the most popular late varieties. Hardy, very large and productive. Bush a strong grower. Very desirable for home use and market.

GOLDEN QUEEN - Yellow. Large. hardy, good quality and beautiful fruit. Said to succeed in all sections, and should be in every home garden.

LOUDON-Red. Of the earliest, and hangs to the last. Large size and solid. The Rural New Yorker says: "The Loudon is the coming market Raspberry."

MARLBORO-Strong grower and very productive. Is said to be earliest and best.

MILLER-Very early. Very productive. Fruit large, bright red, fine color. Excellent shipper.

SHAFFER'S COLOSSAL-Late. Purple. Said to be "Largest in the World." 


\section{CAMPBELL'S EARLY GRAPE.}

Planters of this grape will find herein some very important information on this subject.

Points of special merit in Campbell's Early Grape are:

A very strong, rigorous, hardy vine, with thick, healthy, mildew-resisting foliage, and perfect, self-fertilizing blossoms; and bearing abundantly. Clusters very large, usually shouldered, compact and handsome, without being unduly crowded. Berries large, nearly round, often an inch or more in diameter; black with light purple bloom; skin thin but very tenacious, bearing handling and shipping admirably. Flavor rich, sweet, slightly vinous; pure with no foxiness, coarseness or unpleasant acidity from the skin to the center. Flesh rather firm but tender and of equal consistency, parting easily from its ferr and small seeds. As more than one-third of the American people do not and will not swallow grape seeds, we consider this a strong point in favor of Campbell's Early and a matter of trade well worth earnest attention, for as the late Prof. Lintner, New York State Entomologist, well said in his letter, previously published by us, "No GRAPE SEEDS MAY BE SAFELY SITALLOWED." Its early ripening is at the same time with Moore's Early and at that time the quality of Campbell's Early is fully as good as Moore's Early. After that time the quality of Campbell's Early steadily improves for from two to six weeks so its season is not only very early but is also medium and late. In short you can pick them from early to late as you choose. Moore's Early, Worden, Concord, etc. will not stay on the vines in this way. Campbell's Early, with us, bears about three times the amount of fruit as does Moore's Early. It has very remarkable keeping qualities. In different years it has hung upon the rines in our orvn vineyard sound and perfect, for TEN IVEEKS or more after ripening, with no tendency to shell off or fall from the stems. A few clusters were put in cold storage on September 15 th and taken out the 1.5 th of December, apparently as perfect as when stored, and seeming as though they might have been kept in good condition until Spring. As a good keeper and shipper it is believed to be unequaled by any other American grape.

Campbell's Early vines are now being bought in large lots by careful, wide awake vineyardists who want a grape which will hang on the vines, will not crack and which will keep and can be marketed at advantageous times instead of having to be forced on the market on some special day to avoid cracking and shelling. These vineyardists want a grape which will bring profitable returns instead of possible losses and which will fill the bill for people who are able and willing to pay a better price for something better in quality than the common kinds of grapes.

TVe have never known a bud of Campbell's Early to be hurt by frost. In our own vineyard they have stood 18 degrees below zero without any injury.

Campbell's Early is inclined to overbear, so when this occurs the blossoms (o: fruit when small) should be thinned or the vine and fruit will probably suffet the following year.

We have had unpleasant experience resulting from the overbearing of this grape the first fruiting year. It is a short jointed variety and in the first bearing year of our vineyard the crop was simply immense. The vines were heavily loaded with large, beautiful clusters, and feeling we had a larger crop than had ever been seen before on young vines, we invited the principal vineyardists in our vicinity to see for themselves our vineyard. The next year showed that the big crop had weakened and nearly ruined the vines. They made very little growth of wood with bunches plenty but small and poorly filled. In short, the roots were not old enough and consequently not large enough to carry the immense crop of the preceding year. 


\section{Campbell's Early Grape.--Continued.}

We were at first considerably disheartened and were almost inclined to pull out and burn all the vines. Fortunately we did not do this, as we next season. cut off nearly all the blossoms, gave good cultivation, and the nextyear we were able from this same vineyard, to show at the PAN-AMERICAN, bigger bunches and more of them than were shown of any other grape. The next year we had double the wood that we had the previous year. The vineyard is now in elegant condition, I do not know of a thriftier one.

A grape that will succeed in Massachusetts will do likewise in the Middle, Western and other New England states.

We showed this grape at the Pan American Exhibition in a (to us) new method. We showed it in plates in the usual way and that those interested might have an opportunity to taste them, we put them in by the hundred baskets. Judging by the number of orders we have received from this way of showing and giving away of the fruit we conclude that we don't care to show fruit in future in any other way.

Campbell's Early at the Pan American seemed to be the only grape talked about. Go to any table where it was shown, select the best looking black grape and it was Campbell's Early. No other black grape (not excepting Eaton or McPike) showed either as large bunches or berries or delicious flavor as Campbell's Early.

This grape has taken First Premiums too numerous to mention and when placed in competition with other varieties, and properly scored, there isn't another black grape in America which can stay in its company.

\section{MEDALS, \&c.}

We were awarded Gold Medal, Silver Medal and Diploma from the Pan-American Exhibition in 1901. Wilder Silver Medal in 1897 also Wilder Silver Medal in 1901 from American Pomological Society. Medal of Excellence from American Institute in 1897 .

\section{JOSSELYN GOOSEBERRY.}

\section{A Magnificent Success. It has no Rival.}

If you have not this gooseberry you have not the best and most profitable one in the World.

\section{TESTIMONIALS.}

We have usually printed a large number of testimonials from friends of these fruits. As we view the large number of new ones on hand which we have never printed we see we have not nearly enough room for them all. Our kind friends mostly like to see their good words in print after they have taken the trouble to write them, so as we cannot print them all we do not print any in this issue. 


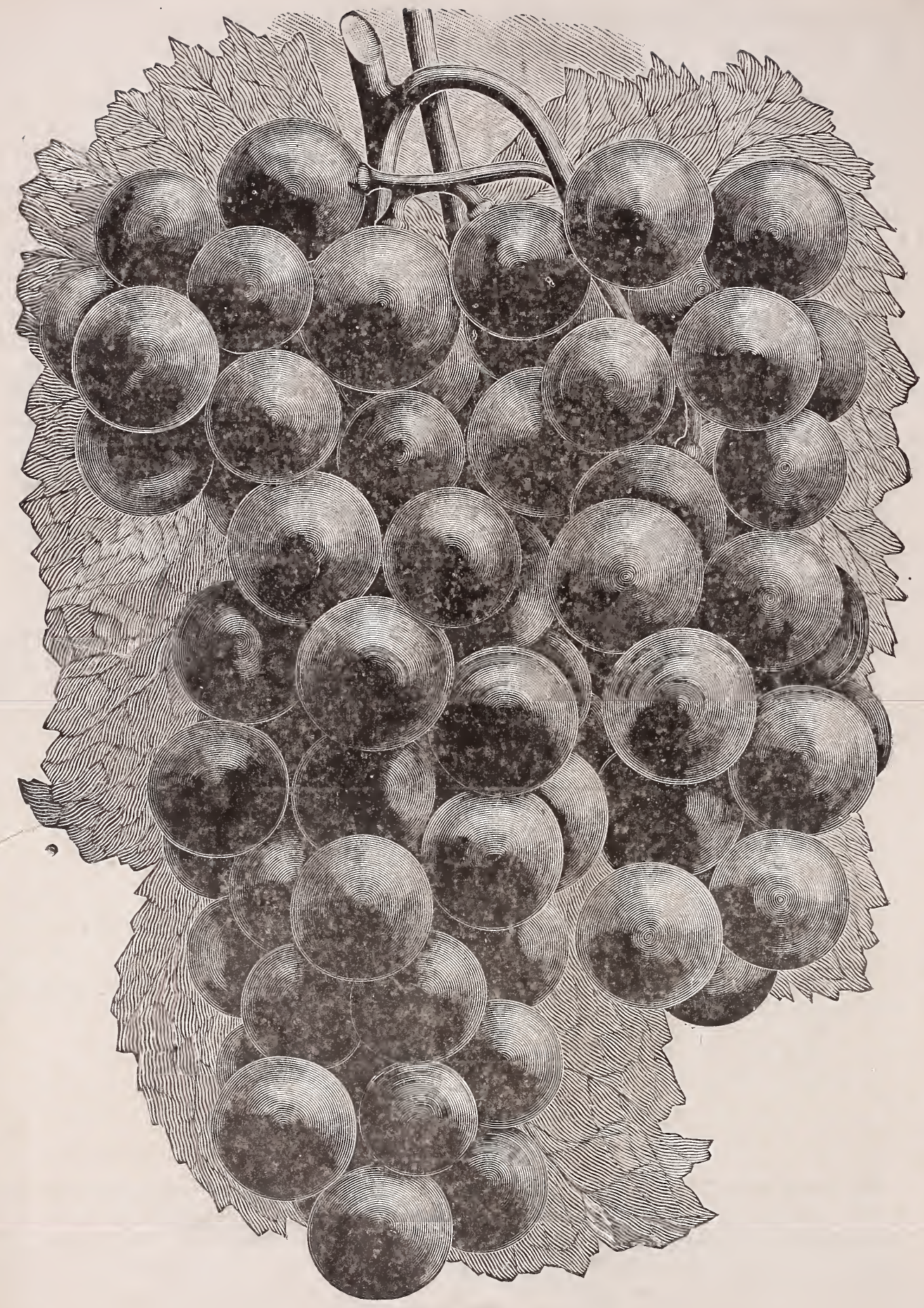

CAIMPBELL'S EARLY.

PHOTOGRAPHED FROM NATURE. EXACT SIZE. 